\title{
Eurostudia
}

\section{A Book, a Securitate File, and a Research Project. On Gossiping and Ethnography}

\section{Barbara Thériault}

Volume 10, numéro 1, 2015

From Today's Observation Post: Collaboration and Resistance under Communism

Vues du poste d'observation du présent : collaboration et résistance sous le communisme

Kollaboration und Widerstand im Kommunismus - Betrachtungen aus heutiger Sicht

URI : https://id.erudit.org/iderudit/1032439ar

DOI : https://doi.org/10.7202/1032439ar

Aller au sommaire du numéro

Éditeur(s)

Le Centre canadien d'études allemandes et européennes

ISSN

1718-8946 (numérique)

Découvrir la revue

Citer cet article

Thériault, B. (2015). A Book, a Securitate File, and a Research Project. On Gossiping and Ethnography. Eurostudia, 10(1), 1-10.

https://doi.org/10.7202/1032439ar
Résumé de l'article

Katherine Verdery's latest book, an ethnography of the Archive of Romania's Secret Police and the permission to copy and study a Securitate file, that of Iuliana, represents, for the author, the opportunity to write an unusual book review. Superposing the book and the file allows her to reflect on the work of secret police officers and that of ethnographers as well as questioning the practice of the sociological observer. As it turns out, the file adds a new dimension and an interpretation key to the book: beyond the importance of networks or social relationships as material secret police officers and ethnographers share, it discloses gossip as an empirical source and a recruitment technique. Centering on gossip helps the author in reformulating one of the book's central arguments and delineating the contours of the "bourgeois," a figure at the core of a new research project. The extreme character of the two cases at hand-material constituted toward a political end-sheds light on the relations ethnographers entertain to their informants as well as to dilemmas of research, which might otherwise remain unseen.
Tous droits réservés $@$ Le Centre canadien d'études allemandes et européennes, 2015
Ce document est protégé par la loi sur le droit d'auteur. L'utilisation des services d'Érudit (y compris la reproduction) est assujettie à sa politique d'utilisation que vous pouvez consulter en ligne.

https://apropos.erudit.org/fr/usagers/politique-dutilisation/ 


\title{
Barbara Thériault
}

Université de Montréal

\begin{abstract}
:
Katherine Verdery's latest book, an ethnography of the Archive of Romania's Secret Police and the permission to copy and study a Securitate file, that of Iuliana, represents, for the author, the opportunity to write an unusual book review. Superposing the book and the file allows her to reflect on the work of secret police officers and that of ethnographers as well as questioning the practice of the sociological observer. As it turns out, the file adds a new dimension and an interpretation key to the book: beyond the importance of networks or social relationships as material secret police officers and ethnographers share, it discloses gossip as an empirical source and a recruitment technique. Centering on gossip helps the author in reformulating one of the book's central arguments and delineating the contours of the "bourgeois," a figure at the core of a new research project. The extreme character of the two cases at handmaterial constituted toward a political end-sheds light on the relations ethnographers entertain to their informants as well as to dilemmas of research, which might otherwise remain unseen.
\end{abstract}

Iuliana is an acquaintance. She happened to mention her Securitate file-the secret police of Romania between 1948 and 1990—on a few occasions over the years. What she said last time when she referred to her file and the work of officers resonated with that of fieldwork sociologists.

"Iuliana, dear, would you let me copy your file? I would like to use it in my introduction class to sociology to talk about the work of ethnographers and that of secret police officers. I'm sure my colleague Monica Grigore will help me; she has the language skills and, as a historian, first-hand experience with Securitate files. As for me, you know I have written a book on police 
2 From Today's Observation Post: Collaboration and Resistance under Communism

forces in Germany, East and West, and can claim some experience in comparing cops and sociologists."

Iuliana agreed. Before I could have access to her file, I had time to read Katherine Verdery's 2014 book Secrets and Truths: Ethnography in the Archive of Romania's Secret Police. For ethical and pragmatic purposes, the American ethnographer proceeds like Freud in his Interpretation of Dreams: she looks at her own case, a file of 2780 pages covering the time between 1973 and 1989. She examines knowledge production within the secret services. She quickly notices parallels between her work and that of Securitate officers, something her officers did not fail to see themselves: in their reports, they point to her use of codes, systems of abbreviations, and "conspiratorial" names; they allude to her protecting her sources and the use of recording devices (2014: 6). And from that, they inferred she was a spy.

Beyond the practices of information gathering, Verdery also examines the use of informers as a tool of information and knowledge production. ${ }^{1}$ She takes her Securişti, her officers, seriously. Instead of distancing and portraying herself as a victim and a morally superior knowledge producer, she sees the ethnographic value of her file and is attentive to the officers' work while impressively managing to suspend value judgments.

\section{$* * *$}

Iuliana is a young woman from the country's capital who, upon receiving a degree in economics, had to complete a three-year internship in a state enterprise. She was sent to a garment factory in a small town in Transylvania. Having assigned her with the code name "Economista," the Securitate opened a file on her in November 1988 and the reporting began. Her colleagues from the factory (five women and two men), the caretaker of her building and some of her neighbors were asked to report on her. Officers and informers first entered into a relationship. Upon reading the 68-page file, why the file was opened remains an enigma. Indications are made to a friend from

\footnotetext{
1 The Securitate distinguished between officers (full-time professional workers) and informers or collaborators who were paid, promised privileges, or threatened into collaborating. In some cases, people collaborated without their knowledge.
} 
another town who, after having allegedly overheard a conversation, might have tipped Iuliana.

In the reports Iuliana is described as presumptuous (increzuta), arrogant (aroganta), full of herself (plina de sine); critical (critică) of her colleagues and of the firm's direction. Informers report that she makes clear she does not plan to stay long in the enterprise; that she does not socialize with others; that attempts at inviting her fail and are not reciprocated; that she enjoys privileges (such as taking her meals at the party canteen and having connections that speed up the settlement of formalities such as getting an apartment quickly). After a warning (atentionare) from the Securitate, an informer reports that she has grown less critical toward colleagues; is nicer; brags about her connections; has started integrating somewhat in the collective; does not express political opinions. The file contains several documents and a hotchpotch of information such as, for instance, Iuliana having contacts with a Soviet citizen. ${ }^{2}$

"Iuliana, do you recognize yourself at all in these documents, whose organizing principle bears resemblance neither to a biography nor to a curriculum vitae and remains obscure? Do you have the feeling it's about someone else?"

Iuliana's Securişti do not interpret much; they collect and accumulate information; they go on fishing expeditions to gather all sorts of information, trying to find out what Iuliana thinks about the party and the enterprise. Astonishingly, they translate little in the party's official language but for Iuliana's reported "manifestation of hatred" and "negligence in her work." Elements from Iuliana's biography—such as some of her relatives living abroad and her boyfriend, a theology student—are not pursued further nor do

\footnotetext{
${ }^{2}$ The 68-page dossier contains different types of documents and opens with a strategic plan requesting to change the verification dossier (mapă de verificare) into a surveillance dossier with specified goalssuch as installing microphones in Iualiana's apartment-and deadlines. A chronology of the Securitate activities can be reconstructed: the denunciation, requests at other offices (for her, family members, and her boyfriend), the opening of the dossier, informative notes by several informers, the warning (Iuliana is contacted by the Securitate); analysis notes; the decision to change the status of the file; other notes and follow-up on the surveillance (Arhiva Consiliului National pentru Studierea Arhivei Securitatii [ACNSAS], Dosar de urmarire informativă, Fond informativ [FI]).
} 
they seem to be treated as important. Why the file was opened is also an enigma for the officers themselves. They seem to suspect in Iuliana a potentially dissident personality whom they need to prevent from joining in hostile activities or disturbing economic activities; also, they seem to try to find ways for legitimating the existence of the file and their own work.

A Securitate file is, of course, everything but a disinterested source; it is troubled, distorted material constituted toward a political end; yet, I would like to argue that one thing breaks through the reports: gossip. A newcomer to a small town of some 70000 inhabitants, an educated young woman from the capital, Iuliana is at the center of the gossips. What I read in her file is reminiscent of typical gossip-be it malicious or flattering-we exchange at work, say, about recently hired or arrived colleagues and about what we see as petty injustice. Again, there is not much explicit reference to official party language or priorities in the informers' reports. Informers talk about Iuliana the newcomer: they are annoyed by what they see as her air of superiority; are intrigued by her boyfriend who lives in another town and whom she visits every weekend and curious about a relationship they look upon as unusual; they mention what they see as Iuliana's privileges.

Gossip connects Iuliana's file to Verdery's book and facilitates exploration on its core argument. The Securitate knew who takes part in gossiping: those who are already there and are well-connected. In assessing the qualities officers sought in recruiting informers, Verdery stresses that "sociability and social connections" were "extremely important" (2014: 176). Many people in Romania and Eastern Europe, she writes, "became informers because they were deeply embedded in social ties" (2014: 210; Verdery's emphasis); they wanted to "protect their own networks of family and friends" (2014: 210). The Securitate selected them for recruitment for the same reason: "documents from the archives, she notes, instruct that the best people to recruits as informers are those who are well connected" (Verdery 2014: 176).

In her book Verdery is attentive to the relations officers fostered to informers: she suggests that officers expressed interest in informers' personal life and tried to make them feel valued (2014: 174); according to an officers' manual, they had to try "to be comradely but not too familiar, and to create relations of cooperation that enable the informer to feel he is contributing to 
something important" (2014: 172). Besides attempts at manipulation, the manual stresses the "pedagogical relation" (2014: 172) the officers should entertain to informers in shaping their thoughts (2014: 175) and exerting "positive influence" (2014: 186). ${ }^{3}$

If Verdery provides us with a description of the complex relations officers entertain to informers and notices similarities between her work and that of Securişti, she does not touch upon the relation she fostered to her own informants and the material she collected while doing fieldwork in Romania. Yet I see here another interstice between ethnographers and officers. In a new research project I collect and transcribe gossip. Don't we do this all the time? Perhaps. One thing is certain though: I do so now more than in any of my previous projects. This is, I believe, related to the topic of the project, a study into the bourgeoisie of an East German town in the aftermath of 1989. I too am interested in connected people. My key informant, Jana, is sociable; she speaks the local dialect and has a wide social network. Such an informant is important, more so than in any other of my past projects. Why? Because those I refer to as "bourgeois" are busy people with family, work, and several obligations; I would not get in contact with them without her help.

In defining the bourgeois I do not refer to a social class or a socioeconomic group. Instead, I accentuate one trait: the rules of reciprocity within networks of friends, families, and acquaintances that structure the daily life of certain individuals and, at the same time, the conventions, obligations, and expectations that weigh on them. Because people who share a network with my key informant feel obligated to her, they agree to speak with me and to have me accompany them in their daily life. As Verdery rightly points out, both the ethnographers and the Securişti share in social relationships and networks a common currency (2014: 198); because well-connected people have something to say and have contacts, we rely on them.

\footnotetext{
${ }^{3}$ The relations officers entertained to informers is a question that has been much treated in literature (in his feuilleton, A Cup of Coffee with My Interrogators, Vaculik [1977] tells about his officer trying to persuade him he is a nice human being; in the film Das Leben der Anderen [2006] the Stasi officer is painted as a man nurturing empathy for the persons he had to keep under surveillance; in Przestuchanie [1989/1982], the interrogator falls in love with the detainee; Kundera's character in "Edward and God" [1999 (1969/1968)] knows about his informers' wish to reeducate him and plays with it).
} 
I observe a close affinity between gossiping, networks or social relationships, and my new research object, the bourgeois. Granted, this trait is not limited to the social type; yet, I argue that it is distinctive, characteristic, and one that other groups or types often lack. What is the bourgeois' relation to gossip? In a formula, one could say: bourgeois entertain a sentiment of moral superiority (was besseres zu sein) others often don't have, but their ideal notions of decency and expectations of respectability prevent them from bragging too much about it (es gehört sich nicht). Bourgeois do gossip and make value judgments, but too much gossip is likely to be seen as a transgression associated with a feeling of indecency and possibly guilt; in other words, transgression means being "petit bourgeois."

In delineating the figure of the bourgeois in such a fashion, I draw more on historians (for instance, Joskowicz 2014: 128-129) who stress decency, politeness, tact, and good life than sociologists who insist on economic (classes), political (citizenship), or social (life style) dimensions (Bourdieu [1979] remains to the present day a constant reference in this respect). In my account, the bourgeois is neither a social category nor a predefined group: it cuts across the categories that usually retain sociologists' interest. ${ }^{4} \mathrm{My}$ definition shares a close affinity to its everyday usage in German (as in the expression ein bürgerliches Leben führen, to lead a well-ordered life), more so than references to pre-established categories-and the critique thereof-which English, French, and Romanian languages suggest.

From the point of view of fieldwork sociologists, the bourgeoisie is both a recruitment technique (I use my friend and her connections) and a critique of this technique (I feel—as a "bourgeois" observer myself-uneasy about the way I recruit participants for my study; my 12-year-old daughter also echoed my malaise when she complained that I exploited people in making them obligated to meet me through Jana).

Reading Verdery's book, I imagined Securişti seeking gossip. In contrast to the East German Stasi officers who were, according to Gelletany (1996: 932),

\footnotetext{
${ }^{4}$ Of course, the bourgeois' dilemmas expounded by the social type will, without much doubt, be more present among certain social classes and socioeconomic groups than others. They are likely to share resources (temporal, social, economic) and a material basis (space and channels) for exchanging information (see Elias and Scotson 2008 [1976/1965]; Meyer Spacks 1982).
} 
reluctant to rely on gossips, the Securitate got people talking as a way to control and gather information that might, one day, comes in handy; seen from the bourgeois outlook, the Securitate is a "petit bourgeois institution." Verdery argues that the use of informers as a tool of knowledge production "was parasitic upon basic forms of social life in Romania (as well as elsewhere in Eastern Europe) while pushing those forms in new directions related to the Party's aim of creating the "new socialist person'” (2014: 196). She adds: “(...) secret police work was successful precisely to the extent that persons under socialism were not autonomous individuals but network nodes" (2014: 211). My brief account would stress that these network nodes are less related to socialism than to the bourgeois trait I have outlined. As such, it would give less credit to socialism in creating a new network-node-man and basic social structures; after all, Germany under the Gestapo, was also reputed to be "served by the general populace" (Gellately 1996: 959). The Securitate relied on existing networks-in my account: a bourgeois structure with its rules of reciprocity, expectations, and ensuing dilemmas for obtaining information and attempting to create-in part through clientelism-new networks based on the old ones. ${ }^{5}$

Whereas Katherine Verdery cultivates distance to her file in her ethnography—she even talked to people who informed on her-, another genre, say, an autobiography, would most probably have commanded another attitude on her part. What about Iuliana? She is furious at her officer, the woman who organized the reporting on her. It hurts. Since 1990 having a file certainly has an air of dissidence attached to it; yet, having someone like me examine it is a different matter. What seems, from my perspective, to be gossip and an ordinary dimension of everyday life, certainly evokes in Iuliana all sorts of memories, including some very unpleasant ones.

"For sharing your file with me, I thank you Iuliana."

\footnotetext{
" In two of his 1926 chronicles on post-revolutionary Russia ("Der Aufgestandene Bourgeois" and "Jewgraf oder der liquidierte Heroismus"), Joseph Roth (2013a [1926], 2013b [1926]) writes about "socialist network nodes" as a new kind of bourgeoisie.
} 
Verdery's ethnography and Iuliana's permission to copy and study her file became the opportunity for writing this unusual book review, for defining the bourgeois, and for questioning my own practice. Like a magnifying glass, these two extreme cases reveal what I do when I recruit participants to my study. And now I know: ethical problems are yet to come.

My key informant, whose real name is not Jana, takes pride in working on my project. She also comes to adhere, in her daily activities, to the social type I delineated, and seems to have become more bourgeois than she was in the past. We joke about it and her emails often end with smileys. According to situations she plays differently with her paper alter ego. She both expresses and hides herself. She has, for instance, recently mentioned to me that she had not posted the article I wrote on her on Facebook, though she has sent it to some friends: "it's OK, but the whole world doesn't have to know [about it]" (ist ok, muss aber nicht jeder wissen).

I will publish my next piece in the town's daily newspaper. My bourgeois contacts make this possible. This is good news, but it is also trickier because my key informant's parents and friends read the paper. There is of course nothing conspiratorial about my work and I am pleased when Jana and the people I observe come to reflect on themselves while reading me. Yet, I would certainly feel uneasy to write something about, for example, racist comments I might hear while gossiping. In any case, the way I would write about it-possibly with irony, the weapon developed historically by the bourgeoisie (Musil 1995 [1952/1930])—would play, I am sure, an important role in touching upon such issues. This is to say that such problems are solved while writing and demand tact on the part of the sociologist (Simmel 1950 [1908]: 305-376; Disselkamp, 2012: 158).

No wonder many people have chosen fiction as a genre when writing about secret files or gossips or, as Verdery (see also Garton Ash 1998), have taken their own file as a case. 


\section{Bibliography}

Bourdieu, P. (1979). La distinction. Critique sociale du jugement. Paris, Minuit.

Disselkamp, A. (2012). "Le secret et la connaissance interpersonnelle: un fondement original du lien social," Sociologie et sociétés 44(2): 143-163.

Elias, N. and J. L. Scotson (2008 [1976/1965]). The Established and the Outsiders. Dublin, University College Dublin Press.

Freud, S. (2008 [1900]). The Interpretation of Dreams. Oxford, Oxford University Press.

Garton Ash, T. (1998). The File: A Personal History. New York, Vintage Books.

Gellately, R. (1996). "Denunciations in Twentieth-Century Germany. Aspects of Self-Policing in the Third Reich and the German Democratic Republic," Journal of Modern History 68(4): 931-967.

Joskowicz, A. (2014). The Modernity of Others: Jewish Anti-Catholicism in Germany and France. Stanford, Stanford University Press.

Kundera, M. (1999 [1969/1968]). "Edward and God." Laughable Loves. New York, Harper Perennial, p. 241-287.

Meyer Spacks, P. (1982). “In Praise of Gossip," The Hudson Review 35(1): 19-38.

Musil, R. (1995 [1952/1930]). The Man without Qualities. New York, Alfred A. Knopf Editor.

Roth, J. (2013a [1926]). "Le bourgeois ressuscité" ["Der Aufgestandene Bourgeois"], Sociologie et sociétés 45(2): 331-333.

—. (2013b [1926]). "Jewgraf ou l'héroïsme liquidé" ["Jewgraf oder der liquidierte Heroismus"], Sociologie et sociétés 45(2): 335-338.

Simmel, G. (1950 [1908]). "The Secret and the Secret Society." The Sociology of Georg Simmel, edited by Kurt H Wolff. Glencoe, Illinois, The Free Press, p. 305-376.

Thériault, B. (2013). The Cop and the Sociologist: Investigating Diversity in German Police Forces. Bielefeld, transcript.

Vaculík, L. (1977). "A Cup of Coffee with My Interrogator," Index on Censorship 6(4): 3-6.

Verdery, K. (2014). Secrets and Truths: Ethnography in the Archive of Romania's Secret Police (Natalie Zemon Davies Annual Lecture Series). Budapest / New York, CEU Press. 
10 From Today's Observation Post: Collaboration and Resistance under Communism

\section{Filmography}

Das Leben der Anderen (2006). Florian Henckel von Donnersmarck.

Przestuchanie (1989/1982). Ryszard Bugajski. 